Received September 19, 1969

${ }^{1}$ Herzenberg, L. A., and Roosa, R. A., Exp. Cell Res., 21, 430 (1960).

${ }^{2}$ Snell, G. D., and Stimpfling, J. H., in Biology of Laboratory Mouse (edit. by Green, E. L.) (MeGraw-Hill, New York, 1966).

${ }^{3}$ Fedoroff, S.. In Vitro, 2, 155 (1967).

${ }^{4}$ Paul, J., Cell and Tissue Culture (Williams and Wilkins, Baltimore, 1965).

${ }^{5}$ Klein, E., and Klein, G., J. Nat. Cancer Inst., 32, 547 (1964).

Bagshawe, K. D., and Currie, G. A., Nature, 218, 1254 (1968).

' Killander, D., and Zetterberg, A., Exp. Cell Res., 40, 12 (1965).

${ }^{8}$ Nilausen, K., and Green, H., Exp. Cell Res., 40, 166 (1965).

\section{Transplantation Antigens in the Central Nervous System}

InVESTIGATIONS into the presence of histocompatibility antigens in mouse brain have given apparently conflicting results. Haemagglutinin ${ }^{1,2}$ and cytotoxin ${ }^{3}$ inhibition studies have revealed that the brain has an extremely small capacity for absorbing $\mathrm{H}-2$ antibodies, compared with lymphoid tissues. Brain tissue, however, induces transplantation immunity ${ }^{4}$ and histocompatibility antigens are detected in neurones of the cerebral cortex by immunofluorescence ${ }^{5}$. The selective localization of the specific fluorescence to the neurones can explain these conflicting results, for the number of stained cells represents only a small proportion of the total brain tissue. This will be reflected by a very low absorptive capacity in quantitative inhibition studies.

I report here the detection of transplantation antigens in the cerebellum of three inbred strains- $\mathrm{C} 3 \mathrm{H}, \mathrm{CBA}$ and $\mathrm{C} 57 \mathrm{Bl}$-and further confirmation of their selective distribution in the central nervous system.

Table 1. EXPERIMENTAL DESIGN

\begin{tabular}{|c|c|c|}
\hline Tissue donor strain & Control antisera & Antisera to tissue donor \\
\hline $\mathrm{C} 3 \mathrm{H}\left(\mathbf{H}-2^{\mathbf{k}}\right)$ & $\mathrm{C} 3 \mathrm{H}$ anti-E.L.4* & $\begin{array}{l}\text { C57BI-anti-B.P. } 8 \dagger \\
\text { Balb/C anti-B.P.8 } \\
129 \text { anti-B.P.8 }\end{array}$ \\
\hline $\mathrm{CBA}\left(\mathrm{H}-2^{\mathrm{k}}\right)$ & CBA anti-E.L.4 & $\begin{array}{l}\text { C57Bl anti-B.P.8 } \\
\text { Balb/C anti-B.P.8 } \\
129 \text { anti-B.P.8 }\end{array}$ \\
\hline $\mathrm{C} 57 \mathrm{Bl}\left(\mathrm{H}-2^{\mathrm{b}}\right)$ & C57Bl anti-B.P.8 & $\begin{array}{l}\text { C3H anti-E.L.4 } \\
\text { CBA anti-E.L.4 } \\
\text { Balb/C anti-E.I.4 } \\
\text { A anti-E.L.4 }\end{array}$ \\
\hline
\end{tabular}

$\mathrm{H}-2$ antigens were detected with an indirect fluorescent antibody technique. Acetone-fixed or unfixed cryostat sections of mouse cerebellum were incubated with an alloantiserum known to contain H-2 antibodies, washed and treated with fluoresceinated rabbit antibodies to mouse gamma globulins. The experimental design, materials and methods were the same as those previously reported in detail ${ }^{5}$. Table 1 summarizes the experimental

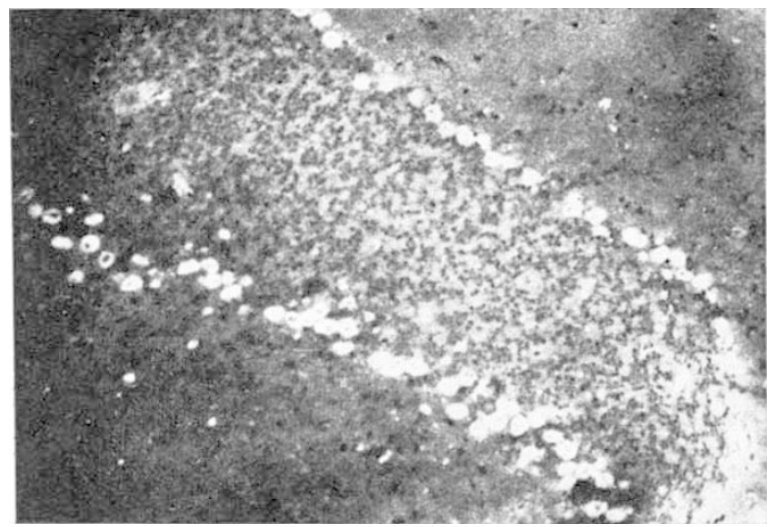

Fig. 1. Tissue section of $\mathrm{C} 3 \mathrm{H}$ cerebellum treated with $\mathrm{C57}$ Bl anti-B.P.8 and the conjugate. Acetone-fixation. $\times 50$.

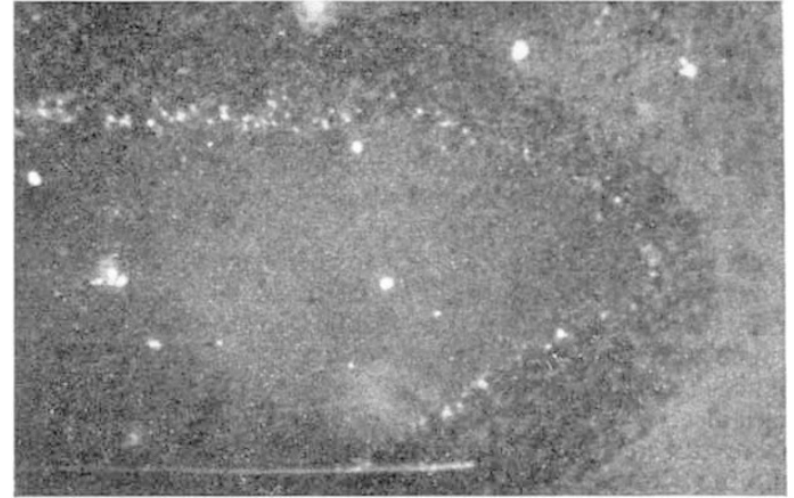

Fig. 2. Tissue section of $\mathrm{C} 3 \mathrm{H}$ cerebellum treated with $\mathrm{C} 3 \mathrm{H}$ anti-E.L.4 and the conjugate. Acetone-fixation. $\times 50$.

design. All antisera were used undiluted and had com. parable haemagglutination and cytotoxic titres. The conjugate consisted of a preparation of IgG from a rabbit antiserum to mouse IgG coupled with fluorescein isothiocyanate. The purification of this conjugate and other technical factors were found to be of critical importance and have been fully described ${ }^{5}$. Five controls were performed in each test to assess the specificity of the fluorescent staining. These included incubation with only the conjugate, the "blocking test", absorption of the positive antiserum with tissue donor cells before use, and substitution of the positive antiserum with normal mouse serum. The most reliable control, however, was provided by the genetic system used in which the same antiserum was employed as a control with syngeneic tissues and as a positive antiserum with allogeneic cells (Table 1).

The results showed that the localization of specific green fluorescence was better defined after acetone fixation. Tissue sections treated with positive antisera displayed bright cytoplasmic staining of the Purkinje cells, the nucleus remaining unstained. The cytoplasm of cells of the inner granular layer was also stained, but the fluorescence was not so intense (Fig. 1). In the "blocking test", there was moderate inhibition of the staining. In all other controls, with or without acetone fixation, specific fluorescence was absent (Fig. 2). Bright vellow autofluorescent granules were observed in all tissue sections. This has been attributed to autofluor. escence of lysozymes ${ }^{6}$.

My results show that the cerebellum, as well as the cerebral cortex, contains $\mathrm{H}-2$ antigenic material and that these antigens are restricted to certain types of cell in the central nervous system. The cells of the granulosa have little cytoplasm and this may explain why their fluorescence appeared less intense than that of the Purkinje cells with abundant cytoplasm. These findings are consistent with the reported ability of cerebellar tissue to induce transplantation immunity ${ }^{4}$.

\section{A. G. Gervais*}

Department of Pathology,

Guy's Hospital Medical School,

London SE1.

Received October 13, 1969.

* Present address: Department of Anatomy, University of Montreal, Canada.

Pizarro, O., Hoecker, G., Rubinstein, P., and Ramos, A., Proc. US Nat. Acad. Sci., 47, 1900 (1961).

${ }^{2}$ Pizarro, O., Rubinstein, P., and Hoecker, G., Guy's Hospital Report, 112, 392 (1963).

3 Basch, R, S, and Stetson, C. A., Ann. NY Acad. Sci., 97, 83 (1962).

4 Bames, A. D., Ann. NY Acad. Sci.,120, 237 (1964).

Gervais, A. G., Transplantation, 6, 261 (1968).

${ }^{6}$ Sarnat, H. B., Anat. Rec., 162, 25 (1968). 